FACTA UNIVERSITATIS

Series: Physical Education and Sport Vol. 15, N 3, 2017, pp. 513 - 522

https://doi.org/10.22190/FUPES1703513S

Professional article

\title{
THE SPORTS INDUSTRY AND ACHIEVING TOP SPORTS RESULTS
}

\author{
UDC 796:351.824.1
}

\section{Zvezdan Savić $^{1}$, Nebojša Ranđelović ${ }^{1}$, Nikola Stojanović ${ }^{1}$, Veroljub Stanković ${ }^{2}$, Violeta Šiljak ${ }^{3}$}

${ }^{1}$ Faculty of Sport and Physical Education, University of Niš, Niš, Serbia

${ }^{2}$ Faculty for Sport and Physical Education, University of Priština, Leposavić, Serbia

${ }^{3}$ Faculty for Management in Sport, Alpha BK University, Belgrade, Serbia

\begin{abstract}
Sport represents a domain where various functions and effects can be manifested. The sports industry today is characterized by modern technology, especially in the sphere of manufacturing sports props and equipment, which significantly helps its development and progress. The sports industry today exists within the social-economic achievements and power of a society. In essence, it should adapt to the new living conditions, work conditions and the conditions in which business is being conducted. Today, it is necessary to invest more in the offer of the sports industry (athletes, results, equipment, equipment, facilities, diagnostics ...), in order to be more efficient in the form of the final product on the market. The industry must adapt to the conditions of the world market (supply and demand). That is why it is sometimes necessary to also expand the range of constituents in order to win a medal - achieve a top sports result. This article will analyze the phenomenon of the modern sports industry as a business model, its production and the realization of the necessary conditions for achieving top sports results and winning medals at big competitions. Naturally, without unity between numerous external and internal factors no top sports results can be achieved. The authors also deal with an analysis of the factors of the sports industry.
\end{abstract}

Key words: sport, industry, results, products, factors.

\section{INTRODUCTION}

Sport today penetrates into all spheres of life of people, forms relations with the state, creating a specific sphere for running a business. Sport also represents one of the most important spheres of entrepreneurial activity that provides, on the one hand, the

Received March 6, 2017/ Accepted January 15, 2018

Corresponding author: Zvezdan Savić

Faculty of Sport and Physical Education, University of Niš, St. Čarnojevića 18, 18000 Niš, Serbia

Phone: +381 $18510900 \cdot$ E-mail: zvezdansavic@yahoo.com 
engagement of a large number of people in the branches of the sports industry, while on the other hand, these branches of entrepreneurship fill state and local budgets at the expense of taxes, which to some extent allows the state to solve various social problems. Consequently modern sports, and therefore the sports industry, are activities of public interest for each state. That is why the state should influence the creation of new conditions for the further development of sports (Solncev, 2012).

Modern - day sport, and thus the sports industry itself, should consist of activities aimed at promoting public welfare for every country. That is why the state should influence the creation of new conditions for the further development of sport. Today sports require cutting - edge working conditions, but also modern experts, who directly participate, work with athletes, although there are spatial differences in organization, sport management and attitude towards sports business. As a third level of income, sports results create objective and subjective factors, as well as direct financing. According to certain economic indicators, sports and the sports industry today are an area of constant growth and progress (Bartoluci \& Škorić, 2009). As an example of the increase in sports events, we cite the example of the increase in the interest for purchasing the rights to broadcast sports competitions as a part of larger events such as the Olympic Games, world, European championships and world cups. Long-term planning and programming, employment of highly educated and professional staff, adequate facilities, modern equipment and props, professional selection of athletes and diagnostics are a prerequisite for achieving top results in sports (Milanović, Jukić, Čustonja, \& Šimek, 2006). As certain authors indicate (Havelka \& Lazarević, 2011), the humanistic concept $^{1}$ of sports advocates for the balanced psycho - physical, psycho - social and functional development of each individual, which in the era of modern sports industry is disappearing and is being suppressed.

World trends in sport, the rapid development of the technology of sports training, the strong development of the sports industry represent the basis for the future work in sport and winning medals. In that context we are faced with the question of what the "sports industry" actually is. Jevtić, Radojević, Juhas, \& Ropert (2011) define the sports industry as a new form of business which focuses on investment and which is a source of profit in industry in general. It represents micro and macro processes which last for a certain period of time and represent the unity of several factors. Sport as an industry is an opportunity for individuals to combine interest in sport and interest in other activities (sports design, programming). Galkin (2006) defines the sports industry as the universality of participants in the economic relations in the field of sports - those who sell and those who buy sports products and services, providers and users of sports information, organizers of sporting events and other operators of the sports market. According to him, the sports industry implies:

- Fans - consumers of sports goods, services and information,

- Companies that produce sports goods, services and information,

- Athletes, trainers, sports clubs, leagues and federations that are both manufacturers and consumers of sports products and information.

The sports industry is defined as a market in which the products offered are directly related to sport, leisure, fitness and products. Sports industry products include: sports, recreational and fitness activities, as well as all material goods and services related to

\footnotetext{
${ }^{1}$ The essential values of a humanistic concept include: equality, inclusion, availability, mass inclusion and exceptionality.
} 
sports, recreation and fitness. In addition, the sports industry also includes management, marketing, finance and other administrative and business goods and services (Pitts, 1988; Pitts, Fielding, \& Miller, 1994).

The sports industry unites several factors, segments and activities. The factors involved in the sports industry include: 1. Management (of large sports events, sports tourism, sports experts and professionals in the field of sport, sports objects, equipment and clothing and facilities for accommodation and high - quality training, bookmakers), 2 . Marketing (sponsorship deals, contracts signed by athletes and clubs, the manufacture and sale of sports equipment and props), 3. Sports results, and 4. Media advertising (Marijanović, 2012)

The extent of the development of the world sports industry today is characterized by indicators of the achieved profit: in 2006 - 107 billion dollars, in 2009 - 112 billion dollars, in 2012 - 129 billion dollars, in 2014 - 146 billion dollars (approximately) (Lednev, 2013).

Today, sports are specifically applied to the general managerial marketing principles of advertising and sales, which also rule in other branches of the business world. The sports market is slowly but consistently formed. Modern - day processes of economic globalization, as trends for overcoming geographic, economic, political and social barriers with the aim of adapting to the current circumstances and the environment are increasingly engulfing the sports industry. The sports industry today is a key part of the national economy (according to Rađo \& Sadžak, 2009). In the countries of the west, the sports industry is a synonym for sport, due to its trend of development and progress. Some authors (Radošević, Ostojić, \& Gavrilović, 2016) believe that financing sports activities should be realized through: membership fees, ticket sales, scholarships, sponsorships and donations, the sale of rights to sporting events and fundraising. Therefore, it can be noted that the sports industry is a specific and special branch that is conditionally different from other classical branches and industries. Sports products and services are intangible and material and have a marketing, financial and sport dimension. Modern social relations are characterized by trends in the sports industry. Achievements of the sports industry based on its products and the services represent a domain where one can prove themselves, realize their potential, but also a domain for sales. The problem of work is treated through the presentation of the sports industry, its factors in contemporary social relations. There is also a need to highlight the ever-growing track of the modern trends in the sports industry, which are a necessary condition for achieving top sporting results and winning medals. Most of the actors today see sport as a sporting battlefield and win, a polygon for the achievement of new sports records, representation of countries and the possibility of implementing new sports contracts. In sports, the material gain that sportsmen provides a safer future. Thus, the sports industry, as a modern social phenomenon, can and should be accepted as a new form of business which should be invested in, from which a significantly greater profit can be achieved. The primary goal of the work would be to approach and present the modern sports industry as a model of world business through the basic factors of the sports industry. The exposed theoretical representation of the sports industry with factors as a model of modern business differs in the European countries in relation to Serbia. In Serbia it has the status of a sports activity. 


\section{THEORETICAL BACKGROUND}

Sport is not only a competition among clubs, athletes, the audiences in their seats, it is also a competition among sponsors (they are not always from the domain of sport), manufacturers of sports equipment, but also sports managers. Victory and winning medals are achieved on the field, but also outside of it. Certain authors (Jukić and Milanović, according to Bjelica, 2015) point out that top sports achievements are the direct result of the entire system of planned, programmed and controlled preparations of the athletes with the aim of meeting the high demands of competitive sport. Victory is achieved through hard work outside the field as well. The victories achieved on the field directly depend on the athletes and opponents (competitors). The conditions outside of the field depend on multiple mutually connected factors, that is, the training process (sports diagnostics, professional work of the trainers, sports doctors, physiotherapists, the use of supplements). The effects of both are equally important and relevant. We are faced with the question of whether the result and motivation of the athlete are equally influenced by the amount of money prescribed by the contract signed with the club, the athlete's desire to sell himself as a player through managers ${ }^{2}$, the need to professionally meet the requirements included in the sponsorship contract in terms of the equipment that the athlete will use, or whether there are higher goals at stake, that is, to defeat one's opponent in the competition and prove oneself (the need to exercise, compete, achieve one's own maximum potential). This is why we view sport as a means of satisfying the needs of individuals, but also the group. Sport today is a public good and should be co-financed by the state which should protect its interests, since the promotion and sports reputation of a state is realized precisely through sports results (Selhanović, 2007). The sports industry is characterized by various products and services offered to users. Dugalić (2008) points out that sports industry is an economic area in which capital and human resources are concentrated. Thus, the sports industry represents micro and macro processes which last for a certain period of time and represent the unity of several factors, segments and activities. The factors of the sports industry include:

1. Management in sport and its role are becoming increasingly more important, especially since people started viewing sport as an integral part of society, in order for it to develop successfully and adapt to important social changes, that is, accept the rules of doing business on the market (Havelka \& Lazarević, 2011). It is expected to contribute to the successful development of sport as a whole, but also of the sports industry as its domain. Management in sport relies on entire systems of institutions and organizations, groups which are also subject to management. According to Bartolucco \& Škorić (2009), a successful manager must possess: knowledge, skill and talent. They also point out that sport management is a process of organizing and managing sports or a sports organization. Dugalić \& Lazarević (2015) point out that they are desirous of the business skills of a good manager: leadership, negotiation and team work. They also point out that there is a perspective for further training of sports managers in both developed and in countries where sport is financed from the state budget. Today, in sports clubs and organizations, it is commonplace that there are many types of managers who need to contribute to their better business (creative manager, fan manager, advertising agency manager, ticketing manager) (Galkin, 2006).

\footnotetext{
${ }^{2}$ In practice it is often the case that managers are those who guide the career path of an athlete since they themselves often invest money in athletes. When large prizes are at stake, they insist on participation and competitions irrespective of the needs of the athletes and coaches.
} 
1.1. Managing sports events is a field which has a special role in the sports industry and sports management. Management especially refers to the organizational processes which lead to the achievement of the set goal, which is a successfully completed sports event. Thus in practice, it "successfully leads an idea to its fruition" (Tomić, 2006). So, management sets, defines and solves set goals. It is directly responsible for the sports results of the club, which is how it directly influences the increase in sports productivity. Sports events thus do not represent only a reflection of an effective training and preparation process of the athlete, but also of other functions of the sports organization, including the activities of the manager and his abilities. Sports events have a double role: a sports-competitive and a promotional and media-oriented role. Winning medals and achieving victory represent the desired outcome of participating in sports, and thus a contribution in sports industry (according to, Savić, 2014). Today, great sums of money are spent on sports competitions and sporting events, which indirectly sets sport and the sports industry in the center of modern social events, and attention. Dugalić (2016) points out that private education models in Serbia have led to a significant increase in the number of employees in the sports sector, higher sports economic efficiency and thus the development of society. For example, there has been a need for more job openings in sport in the period 2006-2016, which is increasing much faster than in other professions (Jevtić et al., 2011, 93). Most of the sporting goals are aimed at achieving victory in competitions (i.e. personal wealth, successful career and gaining personal fame, and in younger categories extending moral and aesthetic norms). Self-esteem, health effects and positive communication are ignored.

1.2. Sports experts and professionals in sport also belong to the domain of the sports industry. It is well-known that sport requires a high level of knowledge, competence and professionalism on the part of sports experts and professionals (doctors, masseurs, psychologists, sociologists, economists) when working with athletes. The role and importance of experts in the field of sport must not be neglected. Successful management of a sports organization has become a requirement for its growth and development and this is precisely where the role of a highly-educated and qualified staff of sports experts can best be seen in sport. In practice we can see that the growth of the sports industry is accompanied by an increasingly greater need for these experts (Šurbatović, 2014). The sports environment today is characterized by the development and increase of sports activities and the competitiveness of sports. As a result, there is a strengthening of trade dimensions of sport and interest in new occupations in sports (Dugalić \& Lazarević, 2016).

1.3. Sports facilities and centers for the accommodation and high - quality training of athletes are important accompanying and necessary conditions for achieving top sports results. These facilities are often the property of the state and ministry of sport, but lately there are also being built by clubs for their own needs (for example, SC "Teleoptik"- FC Partizan, SC "Vujadin Boškov"- FK Vojvodina, SC and the state FSS in Stara Pazova, The Sports Association of Serbia - "Karataš", Kladovo). They are equipped with the most modern facilities, props and with the facilities needed to provide accommodation and board, proper training conditions and room for the rest and recovery of the athletes. Due to the high value of the material resources of sports (tax - financed sports facilities), the state has assumed responsibility for restructuring, while education and research in sport and other competitiveness are left to educational institutions (Dugalić \& Lazarević, 2016).

1.4. Bookmakers are increasingly more often active participants in the sports industry. According to certain estimates, large sums of money "flow" through their hands, and 
through their direct influence, they affect the results and efforts that an individual makes during competitions. Quotas, estimates offered by bookmakers are proportional to the amount of money that individuals involved in betting make. Through bookmakers certain large clubs significantly increase their actual profits. Betting itself is, according to the interpretations of some sociologists and psychologists, increasingly more an area which is encroaching on addiction. The role of the state in this case is not negligible.

2. Sports marketing belongs to sports science and it explains the factors of the sports industry. According to Milojević, sport is a domain of human activity in which marketing plays an important role, since many sports events are mass media events of the highest level (Milojević, 2003, 113). The basis of each sports marketing attempt is reflected in the satisfaction of the buyer (the market) of sports products through loyal competition. People buy things for a variety of reasons, and marketing is the means to gain insight into the needs of the target group and to satisfy these needs with ready-made products. Sports marketing, in the sphere of economy is connected to the manufacture of sports products and provision of services and their supply and demand. Its significance and importance in the sports industry is invaluable. Then rightly ask the question of what constitutes a sports product. Certainly sports products include results, final products, services and manifestations or sports events (Tomić, 2001). Marketing has its place in all forms of planning. The final product in sport is the ultimately prepared athlete, the result and the win. This is the effect of a vigorous training process which often in practice contains elements of illegal activities, but also abuse. The emphasis is on the fact that positive and legal means are predominant, although in practice there are cases, especially when it comes to larger competitions that illegal substances are used and certain abuse in sport can be identified. Athletes, quite often as a result of inexperience (nutritional information, side effects, dosing, means of use...), do not even know how to use certain illegal substances. The sports industry has found its roots in both one type of behavior and the other.

2.1. The manufacture and sales of sports equipment and props represent an important area in the field of the sports industry today. Sales and marketing represent a part of the modern culture of communication in sport. Sport as a social-cultural phenomenon requires financial support from society. On the sports market, the salesperson and the buyer have a mutual interest which can be quite specific (Milojević, 2003). The emergence of sports brands in certain sports directly provides a place on the advertisements and the possibility of sponsoring individual athletes. Often, the contracts signed with sponsors on the annual level are larger than the prize money and the amounts specified in the contracts signed with the clubs. Individual cases of selling sports products are also trends of increasing the sale of sports equipment through practical advertising, i.e., testing or free sports equipment testing for certain sports. ${ }^{3}$ Modern industrial technology certainly contributes significantly to the development of individual sports products, their placement on the world markets, but also partly on changes in the technique and rules of the competition. According to Dugalic also considers $\boldsymbol{a}$ sports diet and sports publishing to be a part of sports products.

2.2. Sponsorship in sport represents the most important part of marketing in sport. It is the link between athletes and large companies with mutual interest. Sponsorships represent

\footnotetext{
${ }^{3}$ Testing skis in most ski centers takes place on a ski slope and the filling out of a questionnaire, that is, assigning points based on certain criteria on the quality, manageability, control of the skis, and overall visual effect. Often the ski and skiing equipment manufacturers cannot even be seen on the items in question (they are masked).
} 
the realization of sports and business goals. On the one hand, athletes require sponsorship contracts to provide them with the top conditions for work and achieving top results, while that sponsor uses the athlete, club and the competition to promote his products and his services on the market (Ganžulić, 2015). An example would be the advertisements found on stadiums, sports halls, uniforms, additions to the names of clubs, leagues, etc. Today sponsorship has become a recognizable form of financing athletes, but also large sports events, that is, for certain companies it is a form of positive investment (the marketing effects are clearly visible in practice). Further examples exist, such as the partnership contract, the mutual interests of Coca Cola and the Olympic movement. Sponsorship is the source of 28.8 $\%$ of all the income on the sports market. If we were to exclude the greatest sporting events and only take into consideration the tempo of growth on other competitions, sponsorships would come in second as a form of generating income, right behind buying the rights to broadcast sporting events. In certain areas sponsorship is the basic component of the income structure. Most professional sports clubs in Europe today are financed through the proceeds generated from: sponsorship deals, donations, advertisements, membership fees, ticket sales, selling TV rights, renting and leasing office space, but also individual activities. The structure of financing professional sports clubs in Serbia is realized through donations, the local government, public office, membership fees, ticket sales and selling players.

3. Sports results are, according to some authors, the most important part of the sports industry, and according to Tomic they can be segmented into: the club image, the sports brand, the sporting event, the sports service and the image of the athlete or team (Tomić, 2001). The image of the club, athlete or team is used by certain sports and companies in order to realize profit, that is, provide a better position for a particular set of products on the market. A sports brand in practice is most often through the use of a contract offered to a marketing agency and profit originations which manufacture products with name brands on them. Sporting events are only one segment of the sporting products and are meant for the public, electronic audiences and potential advertisers. Sports services are defined as the satisfaction of the needs to exercise and compete. The images of athletes are often models for the marketing and sales of sports products (for example, uniforms, shirts, cleats, hats, scarves with number and the names of Messi, Ronaldo, Đoković, etc. on them). The roots of material rewards, compensation and honors awarded to the winners as well as signing professional contracts with teams and sponsors can be traced back far into the past. Even as far back as Ancient Greece in the Olympic Games, the victors enjoyed certain benefits in society. These included the best seats in the theaters, being able to eat in city taverns for the rest of their life, riding off into battle next to their leaders, the freeing of war prisoners who were participants in the Olympic Games, monetary compensation in the amount of the annual pay of professional soldiers, and are just some of the examples of compensations and honors. Today there is more and more talk of certain models of financing and compensating in sport (for example, the American British, Western European, Chinese).

4. Media advertising is another segment and process of the sports industry. It offers untold possibilities. Let us just remind ourselves of the number of sports channels we have access to ${ }^{4}$ through local cable operators, how often sports events are broadcasted on tv, the radio and in the press. Due to large sporting events, national televisions often adapt their existing programming schedules to accommodate them ${ }^{5}$. During large sports

${ }^{4}$ Euro Sport began broadcasting in 1998. (Koković, 2008).

${ }^{5}$ The tennis matches of Novak Đoković were often given priority when compared to other shows. 
broadcasts, half-time intervals represent time for commercials off of which everyone makes money, most of all the owners of tv stations ${ }^{6}$. There is much competition among the media when it comes to buying the rights to broadcast sporting events. The media then directly become active participants in the sports industry. Milojević further points out that top sporting events are increasingly becoming an instrument used by the actors themselves and the large numbers of fans and consumers (Milojević, 2003, 116). We can see an increasing need for connections between the public, the media and sport, in order to create a positive image and reputation on the sports market.

We are in agreement that victory is directly achieved on the field, and that the preparations off the field take place in sports and medical centers (athletic diagnostics, supplements, stimulants meant to increase physical abilities and means of recovery ${ }^{7}$ ). A contribution to achieving success is also made by the media. Certain authors indicate that victory is unfortunately realized in the background where we find the conditions for the realization of top results. We can also point out that there is an opinion that new technologies in sport should be studied as a new scientific discipline. It is considered that new champions with their results and victories will represent a source of profit and material well-being for all the factors on the ladder of success, from top to bottom (Koković, 2008).

The abovementioned facts and factors should be studied in a single interdisciplinary unit, with the final outcome of achieving good sports results.

\section{CONCLUSION}

Sport, as a modern social concept, today solves certain social problems, but also sets new standards. The $12^{\text {th }}$ century symbolizes the beginning of the new sports era. Thus, today's sports principles exist on the principles of profession, profit and sport profits. Throughout history, sport has played a significant role in every society, and therefore has attracted a lot of attention. Throughout history, sport has developed with the constant tendency of increasing sports results and winning as many medals. The sporting result is certainly only a part of a sporting product besides sports event, brand and image. From the first manifestations and needs for competition, proving (part of the fun and entertainment), for military training, it has become a modern profiteering and profitable industry. Modern sport appears in the $19^{\text {th }}$ century in English schools, clubs, colleges and universities. When achieving the primary goal of this work, i.e., approaching and presenting the modern sports industry as a model of a global business, we took care to process only the basic factors of the sports industry. So we can say with certainty that today's top results in sports are modern sports industry in which a lot of money is invested, and from which a lot of money is earned. In such circumstances, athletes lose some of their subjects in part and thus become objects in charge of achieving top results and winning medals. In this way, the sports industry is very helpful with all its sectors, processes and influencing factors. The danger is if an athlete is injured on that road. He is often left to his own devices. We agree in one thing, that sport today is a recognizable polygon for brand promotion, advertising and sales of products and services. The

\footnotetext{
${ }^{6}$ The global largest television business is just advertising.

${ }^{7}$ Sport often takes a turn for the tragic since for the purpose of achieving top results, the bodies of the athletes are exposed to sever strain and the effect of various illegal substances (the substances can even have lethal outcomes with a delayed effect).
} 
emergence of new forms in the sports industry is becoming more and more present. The trend is that they are continuing to develop.

Modern sport is driven by a management system based on scientific development and knowledge derived from scientific studies that tend to be universally valid, unlike an intuitive managerial model. Unlike other industries, the sport has certain distinctive characteristics, making the implementation of the management process unique in more than one aspect. These differences are described by Smith \& Stewart (1999) in connection with the application of specific management techniques in sports clubs. In modern-day society, the basic guidelines of human development in the $21^{\text {st }}$ century are the development of industry, the progress of technology, the development of communication and general globalization, which enables the creation of a specific branch of industry - the sports industry. Modern - day sport is increasingly becoming adjusted to how business is conducted on the market, where the state has maintained its role of financer and helper to sport (primarily at the national level). It has long since been not only a part of physical culture, that is, one form of veil activity, but has turned into a serious economic branch. Quite certainly, the sports industry today can be seen as a branch of industry which is reflected in the building of sports facilities, the manufacture of sports props, clothing and footwear, providing services in terms of sports tourism, the organization of gala sports events and sport as a propagator of consumerism (sports activities and the sports market). So, at the basis of the sports industry we find sports activities and sports philosophy, as well as management in sport.

\section{REFERENCES}

Bjelica, D. (2015). Sport danas I - naučna saznanja i lična iskustva (Sport Today I - Scientific Knowledge and Personal Experiences). Podgorica - Nikšić: Montenegrin Sports Academy. In Montenegrin

Bartoluci, \& Škorić. (2009). Menadžment u sportu. (Management in sport). Zagreb: Faculty of Kinesiology, University of Zagreb. In Croatian

Bartoluci, M., \& Škorić, S. (2009). Menadžment u sportu (Management in sport). Zagreb: Faculty of Kinesiology, University of Zagreb. In Croatian

Dugalić, S. (2005). SWOT analiza i takmičarsko - ekonomska efikasnost, (SWOT analysis and competitive economic efficiency), Belgrade: BK University, Conference Book of Proceedings 1, 4.

Dugalić, S. (2008). Definisanje i konceptiranje sportskog proizvoda (Definition and concept of a sports product). Nova sportska praksa, 1-2, 56-71.

Dugalić, S, (2016). The significance of sport and sthletes bahaviour on forming people's attitudes. Sport Science \& Practice, 6, (1-2), 5-22.

Dugalić, S., \& Lazarević, S. (2015). Special Areas of Sport Management. In M. Stanišić (Ed.), 2nd International Scientific Conference - Synthesis 2015, Book of Proceeding (pp. 339-344). Belgrade: Singidunum University.

Dugalić, S., \& Lazarević, S. (2016). The impact of sports manager education on sport transition: An exploratory study. In S. Lazarević (Ed.), 1st International Conference „, Sport, Recreation, Health”, Book of Proceedings (pp. 58-69). Belgrade: High Sports and Medical School.

Galkin, V.V. (2006). Экономика спорта и cпортивный бизнес [Economy of sports and sports business]. M.: KноPyc. In Russian

Ganžulić, K. (2015). Sportski marketing u košarci, (Sport basketball marketing), Čakovec: Polytechnic of Međimurje in Čakovec, Management of Tourism and Sports. In Croatian

Havelka, N., \& Lazarević, Lj. (2011). Psihologija menadžmenta u sportu (Psychology of management in sport). Belgrade: High Sports and Medical School. In Serbian

Jevtić, B., Radojević, J., Juhas, I., \& Ropert, R. (2011). Dečiji sport (Kids sport). Belgrade: University of Belgrade, Faculty of Sport and Physical Education. In Serbian

Koković, D. (2008). Naličje takmičenja - sport između iluzijada i Olimpijada (Back of the competition - a sport between illusions and Olympics). Prometej: Novi Sad. In Serbian 
Lendev, V.A. (2013). Industriя sportakak arena konkurentno ǔborbbbl (Sports industry as an arena of competition). Internet - žurnal Nauk o vedenie, 6(19). S. 59. In Russian

Marijanović, R. (2012). Menadžment školskog sporta (Management of school sport). Belgrade: Alfa University, Faculty for Management in Sport. In Serbian

Milanović, D., Jukić, I., Čustonja, Z., \& Šimek, S. (2006). Kvaliteta rada u sportu (The quality of work in sport).Zagreb: Summer School of Kinesiology of the Republic of Croatia, (15), 35-47. In Croatian

Milojević, A. (2003). Marketing u sportu (The marketing in sport). Godišnjak za psihologiju, 2(2), 113-119. In Serbian

Pitts, B.G. (1988). Sport product markets. Unpublished manuscript, University of Louisville.

Pitts, B.G., Fielding, L.W., \& Miller, L.K. (1994). Industry segmentation theory and the sport industry: Developing a sport industry segment model. Sport Marketing Quarterly, 3(1), 15-24.

Radošević, I., Ostojić, B., \& Gavrilović, A. (2016). Izvori finansiranja u sportskoj industriji (The sources of finance in sports industry) .Belgrade: Faculty for Sport, Union University "Nikola Tesla". In Serbian

Rađo, I., \& Sadžak, M. (2009).Globalno liderstvo (Global leadership).Sarajevo: Faculty of Sport and Physical Education and Olympic Committee B \& H. In Bosnian

Solncev, I.V. (2012). Роль индустрии спорта в развитии современной экономики, [Eсопотіс and Social Changes: Facts, Trends, Forecast]. Экономические и социальные перемень: факты, тенденции, прогноз, 6 (24), 155-167. In Russian

Savić, Z. (2014). Osnove školskog sporta (Basics of school sport). University of Niš: Faculty of Sport and Physical Education.

Selhanović, D. (2007). Sport - najsnažniji promidžbeni adut (Sport - the most powerful promotional trump card). Medi Anali., (1), 1, 95-102. In Croatian

Smith, A., \& Stewart, B. (1999). Sports Management: A Guide to professional practice. Sydney, AUS: Allen \& Unwin.

Tomić, M. (2001).Marketing u sportu (The marketing in sport).Belgrade: ASTIMBO. In Serbian

Tomić, M. (2006).Osnovi sportske organizacije (The basics of sport organization). Belgrade: Zavod za udžbenike i nastavna sredstva. In Serbian

Tomić, M. (2001). Marketing u sportu - tržište i sportski proizvodi (Marketing in sport - Sport market products). Belgrade: IP “Astibo”. In Serbian

Šurbatović, J. (2014). Menadžment u sportu (Management in sport). Nauka i praksa, 4 (1), 67-70. In Serbian

Www.pwc.ru/sportsoutlook www.pwc. (n.d.). Retrieved on January 14, 2017, from the World Wide Web: http://www.bing.com/cr?IG=E13C0CDB05FC4174B1E1638D98D43D60\&CID=007E4E87D1B465E538 6E448DD0856454\&rd=1\&h=-ZT3x8qeoJq8ADu_5LywDJrAR0-82-

b6b_JYrrEPNyw\&v=1\&r=http $\% 3 \mathrm{a} \% 2 \mathrm{f} \% 2 \mathrm{fwww}$.pwc.com $\% 2$ fua $\% 2 \mathrm{fru} \% 2 \mathrm{fpress}-$ room $\% 2$ fassets $\% 2$ fchanging_the_game_ru.pdf\&p=DevEx,5083.1

\section{SPORTSKA INDUSTRIJA I VRHUNSKA SPORTSKA OSTVARENJA}

Sport predstavlja poligon ispoljavanja raznovrsnih funkcija i efekata. Sportsku industriju danas karakteriše savremena tehnologija posebno u sveri izrade sportskih rekvizita i opreme, koja značajno pomaže rastu $i$ napretku sportske industrije. Sportska industrija danas egzistira u okvirima društveno - ekonomskih dostignuća i moći jednog društva. U osnovi ona treba da se prilagođava novim uslovima života, rada i poslovanja.Neophodno je sve više ulagati u ponude (sportiste, rezultate, opremu, rekvizite, objekte, dijagnostiku), kako bi krajnji proizvod bio efikasnije plasiran na tržištu. Industrija se mora prilagođavati uslovima svetskog tržišta (ponude i potražnje). Stoga je nophodno nekada i proširiti činioce, da bi se osvojila medalja - postigao vrhunski rezultat. Rad obrađuje pojavu savremene sportske industrije kao modela biznisa, njene proizvode i ostvarivanje neophodnih uslova za postizanje vrhunskih sportskih rezultata i osvajanje medalja na velikim takmičenjima. Svakako, da bez jedinstva više spoljašnjih i unutrašnjih faktora nema vrhunskih rezultata. Autori se takođe bave i prikazom činioca sportske industrije.

Ključne reči: sport, industrija, rezultat, proizvodi, činioci. 